\title{
Identifikasi potensi wilayah Kabupaten Nganjuk sebagai sentra pengembangan produksi sapi potong
}

\author{
Nanang Febrianto *, Jaisy Aghniarahim Putritamara, Awang Tri Satria \\ Fakultas Peternakan, Universitas Brawijaya, Jalan Veteran, Malang, Jawa Timur, 65145 \\ *Correspondence: nanangfeb@ub.ac.id
}

Received: July 16 $6^{\text {th }}, 2019$; Accepted: July 15 ${ }^{\text {th }}, 2020$; Published online: November $26^{\text {th }}, 2020$

\section{Abstrak}

Tujuan: Penelitian bertujuan untuk menganalisis potensi wilayah Kabupaten Nganjuk dalam usaha peternakan sapi potong.

Metode: Pemilihan lokasi penelitian dengan menggunakan teknik purposive. Penelitian menggunakan metode survey. Data penelitian terdiri dari data primer dan sekunder. Analisis data menggunakan analisis deskriptif.

Hasil: Hasil penelitian menunjukkan bahwa wilayah Kabupaten Nganjuk berada didataran rendah dengan ketinggian antara 46-96 meter di atas permukaan laut (mdpl) dan berada di pegunungan dengan ketinggian 150-750 mdpl. Temperatur di dataran rendah berkisar antara $23-33^{\circ} \mathrm{C}$ dengan kelembapan udara $75-78 \%$, di wilayah pegunungan suhu udara berkisar antara $20-30^{\circ} \mathrm{C}$ dengan kelembapan 80\%. Produksi pakan ternak asal limbah pertanian dan perkebunan sebesar 572.594,94 ton/tahun dengan kandungan BK sebesar 276.926,99 Ton. Pemanfaatan lahan kritis yang ditanami hijauan makanan ternak sebesar 913.000 ton/tahun. Kepadatan ternak sapi potong sebesar 1,64 LU/ha.

Kesimpulan: Kesimpulan penelitian Kabupaten Nganjuk merupakan wilayah potensial untuk pengembangan sapi potong dilihat dari potensi agroklimat, potensi sumber daya pakan dan potensi lahan.

Kata Kunci: Potensi wilayah; Pengembangan; Sapi potong; Nganjuk

\section{Abstract}

Objective: The study analyzes the potentiality of Nganjuk Regency for beef cattle production.

Methods: The study used purposive technique for selecting location. Meanwhile, the investigation used survey method. The research data consisted of primary and secondary data. Then, the data is analyzed descriptively.

Results: The results showed that the Nganjuk regency is the lowland (46 to 96 meters above sea level/masl) and montaneous region (150 to $750 \mathrm{masl}$ ). The lowland's temperature ranges from 23 to $33^{\circ} \mathrm{C}$ with humidity $75-78 \%$. The highland's ranges from $20-30^{\circ} \mathrm{C}$ with humidity $80 \%$. Animal feed production from agricultural and plantation waste are as much as 572,594.94 tons/year with a dry matter content of 276,926.99 tons. The use of critical land planted with forage are 913,000 tons/year. The density of beef cattle is $1.64 \mathrm{AU} / \mathrm{ha}$.

Conclusions: The research conclusion states that Nganjuk regency is a potential area for development of beef cattle farming due to its agro-climate condition, feed resource potential and farming productivity potential. 
Keywords: Beef cattle; Farming development; Land potential; Nganjuk

\section{PENDAHULUAN}

Sapi potong mempunyai potensi untuk dikembangkan di Indonesia, karena didukung dengan sumber daya alam yang berlimpah, seperti pakan dan iklim tropis yang cocok untuk peternakan sapi potong. Usaha penggemukan sapi potong merupakan usaha yang potensial dalam rangka pemenuhan swasembada daging sapi nasional dan diharapkan dapat mengurangi ketergantungan terhadap impor sapi dan daging sapi [1].

Selain itu peningkatan kesadaran mengkonsumsi pangan bergizi mengakibatkan pola konsumsi berubah dari konsumsi karbohidrat ke arah konsumsi protein hewani. Dirjennakkeswan [2] menunjukkan tahun 2016 pangsa konsumsi daging per kapita/tahun daging sapi menempati posisi ketiga sebesar $0,42 \mathrm{~kg}$ $(6,15 \%)$, daging unggas 5,74 $\mathrm{kg}(84,61 \%)$ dan sisanya konsumsi daging ternak lainnya 0,63 $(9,23 \%)$. Kebutuhan daging sapi untuk konsumsi dan industri tahun 2016 sebesar 620 ribu ton. Produksi daging sapi sebesar 539 ribu ton $(86,93 \%)$, sehingga terdapat kekurangan penyediaan sebesar 81 ribu ton $(13,07 \%)$. Kekurangannya dipenuhi dari impor sapi hidup dan daging sapi. sapi hidup sebanyak 296 ribu ekor (setara dengan daging 52 ribu ton) dan impor daging sapi beku sebanyak 29 ribu ton.

Kondisi tersebut memungkinkan untuk pengembangan peternakan sapi potong baik untuk mencukupi konsumsi dalam negeri maupun ekspor. Kesenjangan antara produksi dan konsumsi daging sapi jika tidak diantisipasi dengan peningkatan produksi di dalam negeri, akan menyebabkan Indonesia selalu bergantung pada impor. Salah satu program yang di canangkan pemerintah untuk mengurangi ketergantungan impor adalah melalui program swasembada daging sapi dan upaya khusus sapi induk wajib bunting. Jawa Timur mempunyai potensi pengembangan usaha ternak sapi potong ditinjau dari potensi sumberdaya alam seperti ketersediaan sumberdaya lahan, pakan, sumberdaya ternak, sumberdaya manusia serta permintaan. Badan Pusat Statistik [3] menyebutkan populasi sapi potong di Jawa Timur tahun 2016 sebesar 4.407.807 ekor (27,5\% dari total populasi di Indonesia). Populasi tersebut tersebar di beberapa kabupaten yang merupakan sentra ternak sapi potong. Badan Pusat Statistik [4] menambahkan bahwa Kabupaten Nganjuk merupakan salah satu daerah yang mempunyai populasi cukup besar, dengan populasi tahun 2013 sampai 2016 mengalami peningkatan rata-rata $3,14 \%$ per tahun. Populasi tahun 2013 sebesar 134.255 ekor, 2014 134.566 ekor, tahun 2015138.522 ekor dan tahun 2016138.601 ekor.

Usaha ternak sapi potong di Kabupaten Nganjuk merupakan salah satu bagian penting dalam pembangunan sektor pertanian. Kegiatan ekonomi yang berbasis peternakan merupakan salah satu kegiatan ekonomi yang memiliki prospek yang menggembirakan. Berdasarkan latar belakang yang diuraikan, maka dirumuskan permasalahannya adalah bagaimana potensi yang dimiliki kabupaten Nganjuk dalam pengembangan sapi potong. Tujuan penelitian adalah untuk menganalisis potensi wilayah di Kabupaten Nganjuk dalam usaha peternakan sapi potong.

\section{MATERI DAN METODE}

Penelitian dilakukan di Kabupaten Nganjuk, penentuan lokasi dipilih secara purposive dengan pertimbangan bahwa lokasi tersebut merupakan salah satu daerah dengan populasi sapi potong terbanyak di Jawa Timur (5 persen dari total populasi Jawa Timur). Metode yang digunakan dalam penelitian adalah metode survei yaitu mengambil sampel dari suatu populasi dengan menggunakan kuisioner sebagai alat bantu dalam pengambilan data. Kumalaningsih [5] menambahkan tujuan survei adalah mendapatkan gambaran yang benar tentang suatu peristiwa tertentu atau terjadi di suatu lokasi dalam suatu daerah.

Responden dalam penelitian ini adalah peternak sapi potong. Penentuan responden dilakukan secara purposive sampling dengan 
kriteria pengalaman beternak minimal 5 tahun, memiliki ternak 2 ekor induk dan 1 ekor pedet. Penentuan jumlah responden untuk mewakili populasi dilakukan dengan perhitungan rumus Slovin: $n=\frac{N}{1+N \cdot e^{2}}$ [6]. Berdasarkan perhitungan rumus Slovin, diperoleh jumlah responden sebanyak 135 responden.

Metode pengumpulan data yang digunakan dalam penelitian ini adalah dengan cara observasi dan wawancara langsung dengan responden. Data penelitian terdiri dari data primer dan sekunder. Data primer diperoleh melalui observasi, wawancara dan dokumentasi dengan responden berdasarkan kuisioner yang telah disiapkan. Data sekunder berasal dari Dinas Peternakan Kabupaten Nganjuk, Dinas Pertanian Tanaman Pangan dan Perkebunan, Badan Pusat Statistik (BPS) Provinsi Jawa Timur dan Kabupaten Nganjuk. Analisis data menggunakan metode analisis deskiptif kualitatif yaitu analisis yang digunakan untuk menjelaskan fakta dan temuan hasil survey dilapangan. Widodo [7] mengungkapkan bahwa analisis kualitatif terdiri dari tiga alur kegiatan yang terjadi secara bersamaan antara reduksi data, penyajian data dan penarikan kesimpulan yang disajikan dalam kata-kata yang disusun dalam teks. Kepadatan ternak ruminansia dihitung dengan menggunakan Live-stock Unit, satu $\mathrm{Lu}=250 \mathrm{~kg}$ bobot hidup [8].

\section{HASIL DAN PEMBAHASAN}

Kabupaten Nganjuk merupakan salah satu kabupaten di Provinsi Jawa Timur yang terletak di bagian barat. Wilayahnya terletak pada titik koordinat $111^{\circ} 5^{\prime}$ sampai dengan $112^{\circ} 13^{\prime}$ Bujur Timur dan $7^{\circ} 20^{\prime}$ sampai $7^{\circ} 50^{\prime}$ Lintang Selatan. Kabupaten Nganjuk terletak pada ketinggian rata-rata 60 sampai dengan 2.300 mdpl. Luas wilayah Kabupaten Nganjuk (Tabel 1) sebesar 122.434,12 km², dengan peruntukan penggunaan lahan sebagai sawah, tegal, perkebunan, hutan rakyat dan negara, pemukiman dan lain-lain.

\section{Potensi Agroklimat}

Wilayah Kabupaten Nganjuk berupa dataran rendah dan beberapa daerah pegunungan membuat suhu dan kelembapan udara berbeda-beda sesuai topografi tiap daerah. Temperatur di dataran rendah berkisar antara $23-33^{\circ} \mathrm{C}$ dengan kelembapan udara $75-78 \%$, sedangkan diwilayah pegunungan suhu udara berkisar antara 20$30^{\circ} \mathrm{C}$ dengan kelembapan $80 \%$. Daerah yang berada di dataran rendah dengan ketinggian antara 46-96 mdpl, sedangkan wilayah yang berada di pegunungan dengan ketinggian 150-750 mdpl. Jumlah curah hujan tertinggi $7.066 \mathrm{~mm}$ per bulan dan sungai Widas yang mengalir sepanjang $69.332 \mathrm{~km}$.

\section{Potensi sumber daya pakan}

1. Potensi pakan asal limbah tanaman pangan dan perkebunan

Potensi pakan sapi potong merupakan seluruh bahan makanan yang dapat dimanfaatkan oleh ternak sebagai sumber pemenuhan kebutuhan pangan, baik yang berasal dari tanaman (hijauan segar), awetan, limbah pertanian maupun limbah industri pertanian di Kabupaten Nganjuk. Bahan pakan ternak yang biasa digunakan oleh peternak sapi potong di Kabupaten Nganjuk (Tabel 2).

Tabel 1. Pemanfaatan lahan di Kabupaten Nganjuk

\begin{tabular}{clcc}
\hline No. & Klasifikasi penggunaan lahan & Luas area $\left(\mathrm{km}^{2}\right)$ & Prosentase $(\%)$ \\
\hline 1. & Sawah & $42.154,67$ & 34,43 \\
2. & Tegal & $11.621,13$ & 9,49 \\
3. & Perkebunan & $46.000,00$ & 0,04 \\
4. & Hutan rakyat dan negara & $45.978,60$ & 38,39 \\
5. & Pemukiman & $19.135,39$ & 15,63 \\
6. & Lain-lain & $3.498,36$ & 2,86 \\
\hline & Total & $122.434,12$ & 100,00
\end{tabular}

Sumber: Badan Pusat Statistik, 2017b 
Tabel 2. Bahan pakan dan kandungan nutrisi pakan ternak sapi potong

\begin{tabular}{cllc}
\hline No. & Asal bahan & Bahan pakan yang dihasilkan & Kandungan nutrisi \\
\hline 1. & Limbah pertanian & Jerami padi & Serat \\
& & Dedak padi & Energi \\
& & Jerami kedele & Serat \\
& Kulit kedele & Serat \\
& & Batang dan klobot jagung & Serat \\
& & Jerami kacang tanah & Serat \\
2. Limbah perkebunan & Pucuk tebu & Serat \\
& & Kulit kopi & Protein \\
3. & Limbah agroindustri & Polard & Energi \\
& & Empok jagung & Energi \\
& & Tetes tebu & Protein \\
& & Ampas tahu & Protein \\
\hline
\end{tabular}

Sumber: Data primer diolah, 2018

Berdasarkan luas panen tahun 2016, jumlah produksi pakan ternak yang berasal dari limbah pertanian dan industri pertanian tanaman pangan dan perkebunan Kabupaten Nganjuk seperti dalam Tabel 3.

2. Potensi pakan hijauan

Sebagian besar pakan hijauan yang digunakan untuk pakan ternak sapi potong adalah rumput gajah, kaliandra dan rumput lapangan. Hijauan ditanam disela-sela tanaman pokok, di pematang sawah atau pada bantaran sungai. Data produksi hijauan makanan ternak (Tabel 4) berdasarkan pemanfaatan lahan kritis di
Kabupaten Nganjuk.

\section{Potensi lahan}

Produktivitas lahan pertanian

Tujuan pengukuran produktivitas lahan pertanian adalah mengetahui tingkat efisiensi penggunaan lahan pertanian. Semakin tinggi produktivitas lahan pertanian, potensi untuk menghasilkan bahan pakan akan semakin tinggi. Produktivitas lahan pertanian diukur berdasarkan jumlah output bahan kering yang dihasilkan, dibagi dengan luas lahan yang digunakan untuk mengusahakan tanaman pertanian. Integrasi ternak dengan usaha tani baik itu tanaman pangan atau perkebunan merupakan upaya untuk meningkatkan daya

Tabel 3. Produksi pakan ternak sapi potong asal tanaman pangan dan perkebunan tahun 2017

\begin{tabular}{llrcr}
\hline No. & \multicolumn{1}{c}{$\begin{array}{c}\text { jenis pakan yang } \\
\text { dihasilkan }\end{array}$} & $\begin{array}{c}\text { produksi pakan } \\
\text { (ton/tahun) }\end{array}$ & $\begin{array}{c}\text { BK dalam } \\
\text { pakan }(\%)\end{array}$ & $\begin{array}{r}\text { Produksi BK } \\
\text { (ton/tahun) }\end{array}$ \\
\hline 1. & Jerami padi (gogo dan sawah) & $30.887,10$ & 70,46 & $217.632,00$ \\
2. & Dedak padi (gogo dan sawah) & $20.105,71$ & 88,40 & $17.773,45$ \\
3. & Klobot jagung & $8.953,00$ & 59,67 & $5.342,25$ \\
4. & Pollard & $4.361,72$ & 86,00 & $3.751,08$ \\
5. & Tebon jagung & $216.019,81$ & 8,94 & $19.312,17$ \\
6. & Jerami kedelai & $16.003,20$ & 69,14 & $11.064,61$ \\
7. & Jerami kacang tanah & $2.735,07$ & 68,32 & $1.868,60$ \\
8. & Pucuk tebu & $2.545,73$ & 7,04 & 179,19 \\
9. & Kulit kopi & 4,04 & 90,00 & 3,64 \\
\hline & Jumlah & $572.594,94$ & - & $276.926,99$ \\
\hline
\end{tabular}

Sumber: Data primer diolah, 2018 
Tabel 4. Produksi pakan ternak sapi potong asal hijauan, berdasarkan pemanfaatan lahan kritis tahun 2017

\begin{tabular}{llccc}
\hline No. & Jenis lahan & $\begin{array}{c}\text { Luas lahan } \\
(\mathrm{Ha})\end{array}$ & $\begin{array}{c}\text { Produksi HMT } \\
\text { ha/tahun (Ton) }\end{array}$ & $\begin{array}{c}\text { Produksi HMT } \\
\text { (Ton/tahun) }\end{array}$ \\
\hline 1. & Potensial kritis & 5.604 & 100 & 560.400 \\
2. & Agak kritis & 2.778 & 75 & 208.350 \\
3. & Kritis & 2.770 & 50 & 138.500 \\
4. & Sangat kritis & 230 & 25 & 5.750 \\
\hline \multicolumn{2}{r}{ Jumlah } & 11.382 & - & 913.000 \\
\hline
\end{tabular}

Sumber: Data primer diolah, 2018

tampung ternak dan kepadatan teknis ternak dari satu satuan luas lahan usaha tani. Kepadatan masing-masing ternak beserta nilai konversinya seperti dalam Tabel 5.

Sapi potong merupakan ternak ruminansia yang banyak dipelihara petani di Kabupaten Nganjuk. Bangsa sapi yang dipelihara beragam sesuai dengan berjalannya program Inseminasi Buatan (IB). Sumber ternak sapi potong di Kabupaten Nganjuk mengandalkan pada usaha peternakan rakyat, dengan pola pemeliharaan dilaksanakan secara tradisional, belum mendapat sentuhan teknologi dan kurang berkembang. Peternak sapi potong di Kabupaten Nganjuk mayoritas peternak raktay dengan skala kepemilikan ternak sedikit, modal kecil dan usaha bersifat sampingan. Kondisi tersebut sesuai dengan temuan Mauludin et al. [9] bahwa masyarakat pedesaan banyak bermata pencaharian sebagai petani dan mempunyai usaha ternak seadanya seperti sapi dan kerbau. Sebagian besar merupakan peternakan rakyat dengan ciri skala kepemilikan ternak relative kecil dan penggunaan input teknologi dan inovasi yang relatif terbatas. Lestari et al. [10] menambahkan kondisi usaha peternakan sapi potong di Indonesia sebagian besar merupakan usaha usaha sambilan atau pelengkap, dengan karakteristik utama jumlah ternak yang dipelihara sangat terbatas dan masukan (input) teknologi yang rendah. Skala usaha ternak sapi potong umumnya antara 1 sampai 4 ekor per rumah tangga peternak sapi potong. Orientasi usaha sebagai usaha sambilan yang tidak terlalu mementingkan keuntungan secara finansial.

Sistem pemeliharaan ekstensif juga masih tampak pada sebagian petani ternak, selain sistem pemeliharaan cut and carry, dimana sapi dikandangkan dan hijauan didapatkan dengan merumput di lapangan. Penanaman hijauan rumput unggul telah dilakukan sebagian kecil petani, namun masih dalam luasan yang sangat kecil sehingga tidak dapat dijadikan untuk pemenuhan kebutuhan ternak setiap hari. Hijauan tersebut biasanya hanya dipanen saat petani tidak punya cukup waktu untuk merumput di tempat yang jauh, pemanfaatan limbah tanaman pangan masih terbatas pada limbah segar, seperti sisa tanaman janten (jagung) dan limbah tanaman kacang tanah. Alternative pakan lain yang digunakan sebagian besar peternak adalah memanfaatkan jerami padi sebagai pakan ternak. Akhadiarto [11] mengungkapkan bahwa jenis limbah pertanian yang melimpah

Tabel 5. Perhitungan konversi ternak ruminansia

\begin{tabular}{clccc}
\hline No & Jenis ternak & Jumlah (Ekor) & Nilai konversi $(\mathrm{Lu})$ & Skor $(\mathrm{Lu})$ \\
\hline 1. & Sapi potong & 106.360 & 0,700 & $74.452,000$ \\
2. & Kerbau & 1.644 & 0,800 & $1.315,200$ \\
3. & Kambing & 115.893 & 0,065 & $7.533,045$ \\
4. & Domba & 90.554 & 0,065 & $5.886,010$ \\
\hline & Jumlah & 314.451 & - & $89.186,250$ \\
\hline
\end{tabular}

Sumber: Data primer diolah, 2018 
di Indonesia adalah jerami padi, tetapi kandungan nutrisi nya tergolong rendah dan termasuk hijauan pakan yang sulit dicerna karena kandungan serat kasarnya tinggi. Pemberian pakan yang rendah kualitasnya menyebabkan kondisi dan fungsi rumen kurang baik.

Berdasarkan kondisi agroklimat tersebut cukup ideal untuk pengembangan usaha peternakan sapi potong di Kabupaten Nganjuk karena sesuai dengan temuan Kalangi [12] bahwa lokasi pemeliharaan ternak sapi potong dapat dilakukan didataran rendah (ketinggian 100-500 mdpl) sampai dataran tinggi (ketinggian $>500 \mathrm{mdpl}$ ) dengan temperatur kandang $25-40^{\circ} \mathrm{C}$ (rata-rata $33^{\circ} \mathrm{C}$ ) dan kelembapan $75 \%$. Selain itu lokasi pemeliharaan sapi potong dapat dilakukan pada dataran rendah yaitu pada ketinggian 100-500 mdpl, hingga dataran tinggi pada ketinggian $>500 \mathrm{mdpl}$. Kabupaten Nganjuk mayoritas wilayah berada didataran rendah, maka berdasarkan ketinggian daerah tersebut sangat potensial untuk pembibitan. Mayulu et al. [13] menambahkan bahwa tujuan pemeliharaan sapi potong yang dilakukan peternakan rakyat adalah untuk pembibitan dan penggemukan. Usaha pembibitan dilakukan di daerah dataran rendah dengan ketersediaan pakan hijauan yang relatif sedikit atau kurang, sedangkan usaha penggemukan terdapat di daerah dataran tinggi dengan ketersediaan pakan relatif cukup.

Kabupaten Nganjuk memiliki curah hujan yang tinggi dan adanya aliran sungai Widas menyebabkan ketersediaan sumber air di Kabupaten Nganjuk cukup melimpah. Sehingga tidak kesulitan menyediakan air untuk kebutuhan minum ternak dan membersihkan ternak. Pendapat ini di pertegas oleh Haryanto et al. [14] bahwa salah satu persyaratan bagi peternakan sapi potong adalah tersedianya air minum yang diberikan secara ad libitum. Air minum dengan jumlah dan kualitas cukup akan menjamin kelangsungan fungsi tumbuh ternak secara normal. Fungsi dari air minum untuk ternak adalah sebagai zat pelarut dan pengangkut zat makanan, membantu proses pencernaan, penyerapan dan pembuangan hasil metabolisme, memperlancar reaksi kimia dalam tubuh, pengatur suhu tubuh dan membantu kelancaran kerja syaraf panca indra. Simamora et al. [15] menambahkan dalam pemilihan lokasi kandang beberapa pertimbangan yang harus di perhatikan: ketersediaan sumber air, lokasi dekat dengan sumber pakan, memiliki areal perluasan, ketersediaan akses transportasi, jarak kandang dengan perumahan minimal $10 \mathrm{~m}$.

Tabel 3 menunjukkan produksi pakan ternak sapi potong asal limbah pertanian tanaman pangan dan perkebunan mampu menghasilkan pakan sebesar 572.594,94 ton/tahun. Produksi pakan tersebut mempunyai kandungan BK sebesar 276.926,99 ton. Berdasarkan aspek kualitas, menurut Hardianto [16] jenis limbah pertanian dan perkebunan yang potensial dilihat dari protein kasar adalah jerami kacang, kulit kedelai dan kulit coklat. Berdasarkan aspek produksi di Kabupaten Nganjuk jerami padi memiliki produksi yang tinggi dengan jumlah 30.887,10 ton/tahun. Masalah muncul ketika memasuki musim kemarau, peternak sapi potong kesulitan mencari rumput atau hijauan segar. Peternak harus pergi ke luar desa untuk mencari jerami di sawah yang sedang panen. Akibat sulitnya mencari hijauan, jumlah dan kualitas pakan yang diberikan ke ternak menjadi berkurang mengakibatkan pertumbuhan ternak kurang optimal. Kleden dan Nenobais [17] melengkapi salah satu limbah pertanian yang diproduksi petani berupa jerami padi dapat digunakan sebagai sumber pakan ternak melalui pengolahan dalam bentuk silase. Pengolahan ini dilakukan karena jerami padi mempunyai kandungan protein yang rendah dan tingginya kandungan serat kasar. Setelah proses amoniasi jerami padi mengalami peningkatan kualitas, protein kasar menjadi $10,12 \%$ dari sebelumnya $8,10 \%$. Peningkatan kandungan protein mengindikasikan bahwa jerami padi dapat digunakan sebagai alternative solusi pakan ternak terutama saat musim kemarau. Lebih lanjut Akhadiarto [18] menambahkan bahwa jerami padi yang diamoniasi mampu meningkatkan konsumsi bahan kering daripada jerami tanpa perlakuan.

Kabupaten Nganjuk dilihat dari potensi pakan hijauan, pemanfaatan lahan kritis 
yang ditanami tanaman hijauan pakan ternak, mampu menghasilkan produksi hijauan pakan ternak sebesar 913.000 ton per tahun dari lahan kritis seluas 11.382 ha. Definisi lahan kritis kritis menurut Nugroho dan Proyogo [19] adalah lahan yang telah mengalami kerusakan yang menyebabkan kehilangan atau berkurang fungsi sampai batas yang ditentukan. Herdiana [20] melengkapi ciri lahan kritis adalah gundul, terkesan gersang dan bahkan muncul batubatuan di permukaan tanah dan pada umumnya terletak di wilayah dengan topografi lahan berbukit atau berlereng curam, selain itu kondisi lahannya menunjukkan penurunan produktifitas tanaman. Lahan kritis dapat ditanami, tetapi kondisi tertentu akan mengalami penurunan produktivitas tanaman. Produksi tanaman pada lahan kritis umumnya tidak lebih dari $25 \%$ dari lahan produktif, tergantung tingkat kekritisan lahan dan jenis tanaman yang ditanam.

Luas wilayah Kabupaten Nganjuk adalah $122.434,12$ ha, jika dihubungkan dengan perhitungan konversi ternak ruminansia bahwa kepadatan ternak dihitung dengan Live-stock Unit, satu $\mathrm{Lu}=250 \mathrm{~kg}$ bobot hidup diperoleh rata-rata kepadatan ternaknya adalah 1,37 Lu/ha. Sedangkan kepadatan ternak sapi potong sebesar 1,64 Lu/ha. Artinya, pada setiap luas wilayah satu ha dapat menampung ternak sapi potong sebanyak 1,64 Lu sapi potong atau setara dengan dua ekor sapi potong bobot $250 \mathrm{~kg}$ dan $160 \mathrm{~kg}$. apabila dihitung kepadatan ekonomisnya (Lu/1000 penduduk) dengan populasi peduduk sebesar 1.053 .568 jiwa (tahun 2016) Sehingga didapat rata-rata kepadatan ekonomisnya 70,67 Lu sapi potong/1000 penduduk. Artinya setiap wilayah yang di tempati 1000 penduduk bisa menampung 70,67 LU atau 100,9 ST.

\section{KESIMPULAN}

Berdasarkan hasil analisis potensi wilayah menunjukkan bahwa Kabupaten Nganjuk merupakan wilayah potensial untuk pengembangan agribisnis sapi potong. Faktor yang mendukung pengembangan antara lain dilihat dari potensi agroklimat, potensi sumber daya pakan dan potensi lahan.

\section{KONFLIK KEPENTINGAN}

Penulis menyatakan tidak ada konflik kepentingan dengan pihak manapun terkait materi yang ditulis dalam naskah ini.

\section{DAFTAR PUSTAKA}

1. Sahala, J., R. Widiati, dan E. Baliarti. 2016. Analisis kelayakan finansial usaha penggemukan sapi simmental peranakan ongole dan faktor-faktor yang berpengaruh terhadap jumlah kepemilikan pada peternakan rakyat di Kabupaten Karanganyar. Buletin Peternakan 40(1):75-82. Doi.org/10.21059/ buletinpeternak.v40i1.9823.

2. Dirjennakkeswan. 2017. Statistik peternakan dan kesehatan hewan 2017 [Internet]. Direktorat Jenderal Peternakan dan Kesehatan Hewan Kementerian Pertanian RI [cited 2018 Jan 21]. Available from: http://ditjennak.pertanian.go.id/ index.html.

3. Badan Pusat Statistik. 2017a. Jawa Timur dalam angka 2016 [Internet]. BPS Provinsi Jawa Timur, Jawa Timur [cited 2018 Jan 4]. Available from https://jatim.bps.go.id/.

4. Badan Pusat Statistik. 2017b. Kabupaten Nganjuk dalam angka [Internet]. BPS Kabupaten Nganjuk, Nganjuk. Available from https://nganjukkab.bps.go.id/.

5. Kumalaningsih S. 2012. Metodologi penelitian: Kupas tuntas cara mencapai tujuan. UB Press. Malang.

6. Sugiyono. 2013. Metodologi penelitian kuantitatif, kualitatif dan R\&D. Bandung: Alfabeta.

7. Widodo, S. 2010. Pengembangan potensi agribisnis dalam upaya pemberdayaan ekonomi pondok pesantren (kajian ekonomi dan sosiokultural). Embryo 7 (2): 111-116.

8. Santosa, S. I., A. Setiadi, dan R. Wulandari. 2013. Analisis potensi pengembangan usaha peternakan sapi perah dengan menggunakan paradigma agribisnis di kecamatan musuk Kabupaten Boyolali. Buletin Peternakan 37(2):125-135. 
Doi.org/10.21059/buletinpeternak.v37i2.24 31.

9. Mauludin, M.A., S. Winaryanto, dan S, Alim. 2012. Peran kelompok dalam mengembangkan keberdayaan peternak sapi potong (kasus di wilayah selatan Kabupaten Tasikmalaya). JIT. 12(1):1-8. Doi.org/10.24198/jit.v12i2.5120.

10. Lestari, R. D., L. M. Baga, R. Nurmalina. 2017. Daya saing usaha penggemukan sapi potong peternakan rakyat di Kabupaten Bojonegoro Jawa Timur. Bulletin Peternakan. 41(1):101-112. Doi.org/ 10.21059/buletinpeternak.v41i1.16906.

11. Akhadiarto, S. 2009. Pengaruh pemberian ransum dari limbah jerami padi dan onggok melalui perlakuan cairan rumen terhadap performan domba. JTL. 10(2):215221. Doi.org/10.29122/jtl.v10i2.1494.

12. Kalangi, L. S. 2014. Analisis efisiensi ekonomi usaha perkembangbiakan ternak sapi potong rakyat di Provinsi Jawa Timur. Disertasi. Sekolah Pascasarjana. Institut Pertanian Bogor. Bogor.

13. Mayulu, H., C. Sunarso, I. Sutrisno, dan Sumarsono. $2010 . \quad$ Kebijakan pengembangan peternakan sapi potong di Indonesia. JPPP. 29(1):34-41.

14. Haryanto, D., M. Hartono, dan S. Suharyati. 2015. Beberapa faktor yang memengaruhi service per conception pada sapi Bali di Kabupaten Pringsewu. JIPT. 3(3): 145-150. Doi.org/10.23960/jipt.v3i3.p\% 25p.
15. Simamora, T., A. M. Fuah, A. Atabany, dan Burhanuddin. 2015. Evaluasi aspek teknis peternakan sapi perah rakyat di Kabupaten Karo Sumatera Utara. JIPTHP. 03(1):52-58.

16. Hardianto, R. 2005. Strategi penyusunan pakan murah untuk mendukung pengembangan agribisnis sapi potong di Kabupaten Lumajang. BPTP Jawa Timur. Malang.

17. Kleden, M. M. dan M. Nenobais. 2018. Upaya pendayagunaan limbah pertanian sebagai pakan unggulan musim kemarau di lahan kering. JPM. 3(1):213-221. Doi. org/10.21067/jpm.v3i1.2656.

18. Akhadiarto, S. 2009. Pengaruh pemberian ransum dari limbah jerami padi dan onggok melalui perlakuan cairan rumen terhadap performan domba. JTL. 10(2):215221. Doi.org/10.29122/jtl.v10i2.1494.

19. Nugroho, S.P. dan T. Prayogo. 2008. Penerapan Sig untuk penyusunan dan analisis lahan kritis pada satuan wilayah pengelolaan Das Agam Kuantan, Provinsi Sumatera Barat. JTL. 9 (2):130-140. Doi. org/10.29122/jtl.v9i2.453.

20. Herdiana, D. 2008. Identifikasi lahan kritis dalam kaitannya dengan penataan ruang dan kegiatan rehabilitasi lahan di Kabupaten Sumedang. Tesis. Sekolah Pasca Sarjana. Institut Pertanian Bogor. Bogor. 